\section{COZINHA PAULISTA CAIPIRA}

Lívia de Oliveira

\begin{abstract}
A boa comida também remete com frequência a um ingrediente que não consta da receita. Aos elogios, quem a fez responde: "Fiz com amor". Soa como um segredo daquela mão, daquele coração, que ao dosar o sal e o azeite tem uma consciência aguda de sua própria medida.
\end{abstract}

Sonia Hirsch (Meditando na Cozinha, p. 65

As lembranças das comidas preparadas por minha avó materna, ainda, estão presentes em minhas memórias gustativas. Eram feitas com desvelo, na busca de ingredientes com substância para alimentar os netos. Era uma cozinha muito paulista e muito caipira, tanto na maneira de preparar, como na escolha dos produtos alimentícios, e no uso de vários trens de cozinha que se colocavam sobre as bocas dos poias (fogões).

A tradição da cozinha caipira está exigindo, de nós paulistas, resgatar, não apenas a culinária, mas, também os ingredientes, os modos de cozinhar e os trens de cozinha que eram e deveriam, ainda, ser empregados. As gerações de agora desconhecem sabores, fazeres e saberes de antanho, muitos nunca ouviram falar em certas guloseimas, certos biscoitos, certos vegetais comestíveis. Ficaram perdidos nos tempos e nos espaços, nos desvãos dos guarda-louças, nos caminhos dos tropeiros, nas escadarias das vivendas, nas mãos das doceiras, nos fundos das canecas de ágata.

1 Professora Emérita do Instituto de Geociências e Ciências Exatas da Universidade Estadual Paulista, UNESP de Rio Claro (SP). liviadeoliveira@yahoo.com.br. $\triangle$ Rua 4, 1229, ap. 101, Centro, Rio Claro, SP. 13500-970.

Geograficidade | v.4, Número Especial, Outono 2014 ISSN 2238-0205
O meu propósito, através da figura ímpar da vovó Bibiana, é trazer até aqui, aquele mundo de minha infância, impregnado daqueles aromas, cores e sabores.

A apresentação seguirá a seguinte ordem: os trens de cozinha, os ingredientes, os fazeres, os comes e bebes, os quitutes e as quitandas.

\section{TRENS DE COZINHA}

As panelas de barro foram substituidas por tachos e caldeirões de cobre ou ferro, e as cuias, pelos pratos de estanho ou ágata.

Rosa Belluzzo (2011, p.44)

Os trens de cozinha são o conjunto de utensílios usados no preparo dos alimentos. O material era variado: barro, ferro batido, louça, ágata, alumínio, cobre. Os apetrechos de cozinha estavam associados aos hábitos culinários e às tradições indígenas, portuguesas e algumas às africanas. Os cheiros penetrantes, os ruídos das colheres de pau, as cores esmaltadas das panelas e o crepitar das lenhas no fogão são reminiscências, ainda, presentes no imaginário e na alegria de participar desses momentos.

Chaleira: vasilha de ferro esmaltada ou não, bojuda, com bico, tampa e asa. Pode ser de vários materiais: ferro, ágata, alumínio e usada para ferver água. Ficava, continuamente, sobre a chapa do fogão. Pronta para ser servida: passar um café quentinho e cheiroso, ou fazer um chazinho de ervas aromáticas, ou, então, para atender a qualquer necessidade (uma garrafa de água quente para os pés; escaldar uma panela). Em geral, a chaleira não era areada, deixava-se aquela crosta porfora. 
Caldeirão: utensílio de metal (ferro, alumínio, ágata) ou barro, de vários tamanhos, redondo, com alça e tampa, usado em geral, para cozinhar o feijão de todos os dias. O caldeirão, também, permanecia horas e horas sobre a chapa do fogão, pois, à lenha, exigia muito tempo para a sua cocção.

Panela: vasilha de metal (ferro, alumínio ou ágata) ou barro, de vários tamanhos, redonda, com cabo longo e tampa. Servia para preparar arroz, legumes, carnes.

Frigideira: panela rasa, redonda, de vários tamanhos, com cabo, podendo ser de ferro ou de alumínio, usada para frigir, fritar os alimentos. Em geral, quando pequena para estrelar os ovos, e maior para fritar pastel, bolinhos, fritadas e mesmo carnes.

Caneca, canequinha, canecão: recipientes com asa, de barro, alumínio ou ágata. A caneca serve até para medidas culinárias, a canequinha para beber o café e o canecão para ferver água, leite ou guardar líquidos.

Assadeira: apetrecho de cozinha para assar, qualquer alimento, em especial as carnes, fazer bolos. São de vários tamanhos, de forma retangular ou redonda, tanto de alumínio, como de ágata, rasas ou mais fundas. Também, denominada de "forma de assar", fala-se "untar a forma".

Tachos: eram de tamanhos diferentes, com asas, e os mais comuns eram de cobre para fazer goiabada, doce de laranja, etc. Ou, então, eram de ferro para ferver as roupas encardidas.

Gamelas: eram de madeira, variando de tamanho e de uso. Serviam para salgar as carnes, os toucinhos. As maiores para lavar os pés e até para alimentar os animais.

Cuscuzeiro: vasilha de barro, com tampa, para cozinhar a vapor.

Peneira: utensílio redondo com aro de madeira ou metal, sendo o fundo formado de tiras ou fios entrelaçados, em geral de taquara, usada para reduzir um alimento a pedaços ou para separar substâncias maiores ou menores. Nelas eram escolhidos o feijão, o arroz, ou outros cereais, também eram passados os grãos do milho verde para fazer pamonha. Não se conhecia o escorredor, que apareceu muito mais tarde. As peneiras eram de vários tamanhos. As grandes serviam para aventar os cereais (feijão, arroz, milho), para lhes tirar as cascas ou ciscos.

Pilão: feito de madeira, era usado como almofariz, servindo para bater, triturar, pilar, socar. Usava-se a "mão de pilão", para socar. Faziam-se paçocas de carne seca, e de amendoim ou para descascar arroz ou milho.

Cuia: era usada como medidas, daí variarem os seus tamanhos. Em nossa casa usávamos a cuia de porongo, mais do que a de cabaça. $O$ porongo é uma trepadeira, com frutos ocos e de cascas duras, e com pescoços mais ou menos longos. Assim era fácil de manejá-las.

Monjolo: consistia em um engenho tosco, movido a água e usado para pilar, moer o milho. Acoplado ao monjolo, estava a "casa de farinha". Entre nós usávamos a farinha de milho branca e a de mandioca era comprada.

Libério Neves, em seu poema "Doação, Elégia 18", publicado na "llustríssima" de 7 de abril de 2013, p. 10, da Folha de São Paulo com suas palavras cantantes, nos diz:

$$
\begin{aligned}
& \text { Vou fluir o rego-d'água } \\
& \text { para mover o monjolo } \\
& \text { em seu compasso longo }
\end{aligned}
$$

Fogão a lenha: era o símbolo da cozinha caipira paulista. Em todo o interior do estado de São Paulo todas as casas possuíam um fogão de alvenaria, com forno e chaminé, para preparar todos os alimentos a serem consumidos. 
Lenha: porção de ramos, achas ou fragmentos de troncos de árvores reservados para servirem de combustível. Minha avó comprava a lenha em feixes, trazida por um carro de boi, conduzido por um lenheiro.

O maior trabalho consistia em acender o fogo, pois, apesar dos acessórios como cascas secas de laranja pendurados no fumeiro, pedaços finos de lenha e jornal amassado, às vezes, da danada da labareda não se fazia... Daí os assoprões, que fole já não se usava (PENTEADO, 2004, p. 74).

\section{INGREDIENTES}

Desde que nasce o homem precisa obter sua alimentação, hidratos de carbono, gorduras, proteínas, sais, água. Deve retirar esses elementos das carnes, dos vegetais e minerais.

Câmara Cascudo (2006, p.18)

Ingredientes é qualquer substância que entra na composição dos alimentos, tanto carnes, verduras, legumes, raízes, frutas, como os temperos.

Carnes: eram as de vaca, porco e frango. Eram preparadas no fogão a lenha, em panelas de ferro. A carne de porco era posta em vinha-d'alhos (molho feito com vinagre, limão, alho, sal e especiarias), pré-cozida, para depois ser assada, até dourar as costeletas, os pernis. O lombo do porco era previamente cozido, nos temperos e ficava guardado em um boião de barro esmaltado, imerso em banha. Quando necessário era retirado um pedaço e frito em uma frigideira. Comíamos muita carne de porco: acrescentados peças (pé, orelha, focinho) no cozimento do feijão.

As postas de carne de vaca eram refogadas, também em panelas de ferro, e assadas aos poucos, pingando um pouco de água de cada vez.
Quando pronta, formava um molho marrom, onde se acrescentavam cebolas e batatas.

Comíamos muita carne picada, o nosso famoso "picadinho de carne" com cenoura, ou chuchu, ou batatinha. Porém, tínhamos um moedor de carne e era moída na hora.

O frango ou a galinha constituíam o cardápio de domingo. $O$ costume era preparar um ensopado com frango "capão", com legumes e engrossado com gemas de ovo e as claras eram cozidas. Usamos muito fazer um virado de frango com farinha branca de milho. Este era sempre levado quando viajávamos. A galinha, quando bem gorda e não botava mais, preparava-se uma canja bem gostosa e substanciosa.

Verduras: são vegetais de folhas verdes e ingeridas como salada ou cozidas. As verduras exigem uma nota a parte. Minha avó saía com uma peneira, andando pelo mato catando as verduras: caruru, serralha, guarana (um tipo de palmito), mostarda nativa, cambuquira (brotos de abóbora), taioba (folha e o tubérculo). Comíamos muita couve e às vezes, chicória e pouco almeirão.

Encontrei esta citação sobre o caruru:

Por exemplo: caruru. Não adianta procurar em feira ou supermercado. Ele só dá em mato, terreno baldio e beira de calçada. É a folhinha mais rica que existe em ferro e vitamina $A$. Macia, de sabor neutro, funciona bem na salada e melhor ainda quando é refogado com alho: lembra um pouco agrião (HIRSCH, 2011, p. 138).

Legumes: são vegetais conhecidos como hortaliças, constituídos de abóbora, abobrinha, moranga, chuchu, pepino, tomate.

Raízes: comumente ingeríamos batata doce, cará (inhame) taioba, mandioca e batata. 
Frutas: estiveram presentes, continuamente. Eram como sobremesas, ou como merendas. Sempre bem fresquinhas. Comíamos as várias bananas (prata, ouro, maçã, nanica), laranjas (lima, baiana, cravo), mexerica, tangerina, lima da pérsia, goiaba, araçá, jabuticaba, abacate, araticum, caqui, abacaxi, uva, etc., etc.

Temperos: cebola, alho e cheiro verde (salsinha, cebolinha), manjerona e nunca usávamos coentro.

\section{Grande Quintal,}

Frutas no tempo certo..

Horta, couve, salsa,

Ervas santas, milagrosas.

(CORALINA, 2009, p. 88)

\section{FAZERES}

São Paulo está a perder a sua tradição culinária e devemos recuperá-la.

Rosa Belluzzo (2008, p.11)

Os fazeres é o preparo dos ingredientes; é a arte de fazer alimentos, com carinho e dedicação. O preparo varia de acordo com os ingredientes. Assim, as carnes eram cozidas, assadas, fritas, è̀s vezes, meio cruas, mal-passadas. Acompanhavam raízes (cará, mandioca, batata) ou vegetais de folhas.

As folhas (couve, repolho, chicória, cambuquira, serralhas, caruru), eram "abafadinhas", isto é, cozidas, destapadas e rápidas. Na couve era dado apenas um "susto". O refogado era a mistura de vários temperos (cebola, alho, cheiro verde) para darem sabor aos legumes (chuchu, abobrinha, abóbora) sempre passados em óleos ou gorduras bem quentes.
Os virados foram presentes na nossa mesa; sempre usando farinha de milho branca. Mamãe não apreciava a farinha amarela: dizia que era meio amarga e tinha um cheiro desagradável. O que acontecia é que a farinha era feita por tia Nhanhã, cunhada de meu pai. Assim, a farinha era cheirosa e saborosa comíamos com mel ou melado. Voltemos aos virados que eram preparados com tudo: verduras (repolho, abobrinha, couve), carnes (de frango e porco). Qualquer sobra do almoço, se transformava em viradinho na janta.

Mas, o virado mais importante, mais tradicional e emblemático da cozinha caipira paulista é o virado de feijão, constantemente com acompanhamentos, com ovo frito, costelinha de porco, arroz branco, couve assustada e torresminho. Era uma festa, que fazíamos a este virado de feijão, conhecido como à paulista.

Outro prato, quase indispensável, era a farofa, sempre elaborada com farinha de mandioca. Fique claro: virado é feito com farinha de milho e farofa é com farinha de mandioca. As farofas acompanhavam todos os pratos (carnes e verduras). As suas confecções variam de família para família. Porém, seguiam certos passos, em uma frigideira se colocava a gordura e fritavam-se as carnes, linguiças, toucinho defumado, ou os ovos e outros temperos (cebola, cheiro verde) e depois, aos poucos, ia-se pondo a farinha. Esta podia ser mais seca ou mais úmida.

Quanto aos fazeres, nos chama a atenção era como vovó fazia o ovo quente. Usava sempre ovos de galinhas que criava. Portanto, sempre fresquinhos. Seus ovos quentes, que eram degustados na própria casca, ficavam no ponto: claras cozidas e gemas moles. Eram preparados sempre iguais. Vovó dizia que rezava ave-marias contadas para ficar exatamente da mesma maneira. 


\section{COMES E BEBES}

Precisamos zelar nas nossas raízes agrícolas e culinárias, nos esforçamos para preservar a herança e o conhecimento de nossos ancestrais.

José Graziano da Silva (Diretor Geral da FAO)

Os comes significavam as comidas quentes ou frias; aquilo que se comia todos os dias; era o trivial; o cotidiano, era:

Pegar os ingredientes, lavar, descascar, limpar, temperar, acender o fogo, botar as panelas e cuidar até aquilo virar uma refeição completa (HIRSCH, 2011, p. 11).

Era isso mesmo, repetidamente, preparar a mesa, cozinhar, comer, retirar a mesa, lavar as louças e panelas. O básico de todos os dias, no almoço e no jantar constituía de feijão com arroz, acompanhado de farinha de milhão branca ou de mandioca, sendo as misturas de um pedaço de carne, ou ovo frito ou cozido, então uma fritada de legumes, ou linguiça; uma verdura cozida abafadinha e uma salada crua de alface, tomate e cebola, ora eram cozidas de chuchu, abobrinha ou batata. Não usávamos pão nas refeições. Vovó dizia que o pão branco era sem sustância, que farinha é que alimentava.

O caldo de feijão nas tardes frias aqueciam nossos corpos e saciavam nossas fomes. Quando ficávamos doentes tomavam um caldo de carne revigorante.

Os engrossados de fubá com couve ou de batatas compunham o nosso cardápio.

Os bebes incluíam os vários refrescos feitos das diversas frutas, que dispúnhamos na estação. Eram principalmente de abacaxi, uva, uvaia, e uma gostosa limonada. Não eram geladas, apenas frescas. Não tínhamos geladeiras, naqueles tempos de outrora. Nas noites geladas, um chazinho bem quentinho de erva cidreira, poejo, hortelã, ervadoce, canela ou camomila, acompanhado de um biscoito ou bolacha.

Dentre os alimentos líquidos, lembranças com prazer matinal o café com leite, pão quente com manteiga, e às vezes, com uma fatia de queijo branco. Degustar uma caneca de garapa recém moída da cana. Oh!, delícia, oh!, gostosura.

Mamãe preparava vários licores. Os mais comuns eram de folha de figo, de mexerica, de araticum, de jabuticaba. Esses néctares dos deuses eram oferecidos após as novenas da Imaculada Conceição, que reuniam os familiares e amigos para a ladainha. E, nós crianças, nessa oportunidade, podíamos bebericar um cálice de licor.

\section{QUITUTES}

Sabores, cheiros e cores dos quitutes provados e aprovados nos primeiros tempos de vida dificilmente são esquecidos.

Angelina Bulcão Nascimento (2006, Nas orelhas)

Quitute é petisco, comida apetitosa, como as iguarias delicadas e saborosas. É um vocábulo de origem angolano e as africanas eram mestres em preparar essas gostosuras, para serem ingeridas fora das refeições. Assim os pastéis recheados de carne, de palmito ou de queijo, e também os bolinhos de arroz, de bacalhau, de verduras, de peixe eram quitutes. O pastel é tão paulista, como é preparado por aqui. Enquanto os bolinhos eram pingados em colheradas e fritos em gordura, os croquetes eram feitos à mão, acertando as formas como pequenos cilindros e depois passados na farinha de rosca e fritos em gordura. Os croquetes podiam ser de carne de vaca e batata moídas, ou 
de carne de galinha ou mesmo de camarão. As empadinhas preparadas com recheio de palmito, ou camarão ou galinha eram apetitosos e muito requisitadas em festas. Estes e outros quitutes eram elaborados para aniversários ou para receber visitas.

\section{QUITANDAS}

Assim, as quitandas, além dos momentos de visita e prosa amigável, normalmente eram servidas na merenda da tarde e na ceia antes de deitar.

Marcos Mergarejo Netto (2009, p. 103)

A quitanda é sempre doce. Esta palavra também procede de Angola. Daí as melhores quitandeiras sempre foram as africanas. As cozinheiras escravas inventavam uma variedade de quitandas para agradar a sinhazinha ou o nhonhozinho. Os biscoitos, os bolos, os sequilhos, as brevidades, os docinhos, constituíam a plêiade de quitandas. Nos interiores dos estados de São Paulo, Minas Gerais e Goiás, ainda usam muito este termo quitanda. Em outros estados a palavra quitanda se refere a pequenas vendas que comerciam frutas, verduras e pequenos pacotes de alimentos.

As quitandas eram guardadas em latas para continuarem crocantes e fresquinhas. Em casa, minha avó não fazia as quitandas, elas eram encomendadas a uma quituteira de mão cheia, que vive no nosso quintal, a Sia Maria: uma africana retinta, alta e com um colo aconchegante, que eu gostava de dormir e sonhar com as guloseimas.

Não se usava servir salgados em festas, como hoje se faz, ficando os doces para uma segunda investida. O costume era apresentar uma farta e bonita mesa de doces, com canudinhos recheados com creme, bombas, cajuzinhos de amendoim, cocadinhas, docinhos de coco e ameixa - os famosos olhas de sogra, que faziam o regalo da meninada, ao lado das tortas e do bolo de aniversário. Não havia brigadeiro (PENTEADO, 2004, p. 51).

Essas minhas lembranças de sabores, olores, cores e dos fazeres das comidas perduram e são intrínsecas ao meu viver de hoje, e da vivência de ontem.

\section{REFERÊNCIAS}

BELLUZZO, Rosa. São Paulo Memória e Sabor. São Paulo: Editora UNESP, 2008. 115p.

CORA CORALINA. Doceira e Poeta. São Paulo: Editora Global, 2009. 143p.

CAMARA CASCUDO, Luis da. História da Alimentação no Brasil. São Paulo: Global Editora, 2004. 954P.

HIRSCH, Sonia. Meditando na Cozinha. Petrópolis: Correcotia, 2011. 175P.

NASCIMENTO, Angelina Bulcão (orelhas). In: MAGALHÃES, Marcelo Campos. Dos Campos à Mesa. Salvador: Fast Design Editora, 2006. 199p.

NETTO, Marco Mergarejo. 60 anos de EMATER, MG. Belo Horizonte: Realização Governo de Minas, 2009. 144p.

NEVES, Libério. Doação. Folha de São Paulo, llustríssima, 7/4/13, p. 10. PENTEADO, Ly. Das Janelas do Casarão... Piracicaba: Gráfica e Editora Degaspari, 2004. 312p. 